IRA-International Journal of Management \& Social Sciences

ISSN 2455-2267; Vol.06, Issue 03 (2017)

Pg. no. 429-439

Institute of Research Advances

https://research-advances.org/index.php/RAJMSS

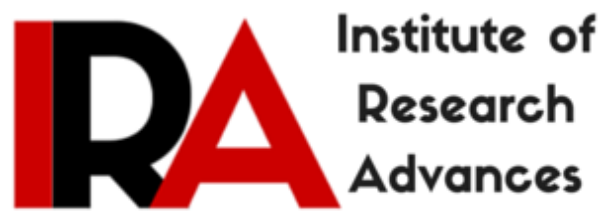

\title{
Tax Regulation and Sustainability of Microfinance Institutions in Masvingo Urban, Zimbabwe
}

\author{
Munyaradzi Duve $^{1}$, Rejoice Mandizvidza ${ }^{2}$, Tendai Chibaya ${ }^{3}$, Moses Nyakuwanika $^{4}$ \\ 1,2,3,4 Great Zimbabwe University, Department of Accounting and Information Systems, \\ P.O Box 1235, Masvingo, Zimbabwe.
}

Type of Review: Peer Reviewed.

DOI: http://dx.doi.org/10.21013/jmss.v6.n3.p9

\section{How to cite this paper:}

Duve, M., Mandizvidza, R., Chibaya, T., \& Nyakuwanika, M. (2017). Tax Regulation and Sustainability of Microfinance Institutions in Masvingo Urban, Zimbabwe. IRA-International Journal of Management \& Social Sciences (ISSN 2455-2267), 6(3), 429-439. doi:http://dx.doi.org/10.21013/jmss.v6.n3.p9

(C) Institute of Research Advances

\section{(cc) EY-NC}

This work is licensed under a Creative Commons Attribution-Non Commercial 4.0 International License subject to proper citation to the publication source of the work.

Disclaimer: The scholarly papers as reviewed and published by the Institute of Research Advances (IRA) are the views and opinions of their respective authors and are not the views or opinions of the IRA. The IRA disclaims of any harm or loss caused due to the published content to any party. 


\begin{abstract}
The study seeks to evaluate the effect of the current tax regulatory regime on the sustainability of microfinance institutions (MFIs) in Masvingo urban. Many governments raise public finance through the taxation of individuals and the business community. Undertaking of this study was mainly motivated by the increase in the number of microfinance institutions after the introduction of the multicurrency system in 2009, but the government is failing to meet its revenue targets. The study was done on 24 loan officers and 8 managers of MFIs. Data was collected using a Likert scale questionnaire. Quantitative data was presented using SPSS. This study found that a tax regulation can enhance the sustainability of MFIs if properly simplified to promote investment in microfinance business through provision of tax exemptions, tax incentives, free registration, simplified record keeping procedures, and reduced tax rates. The study recommends that MFIs should not be heavily taxed if they are to meet a major objective of poverty alleviation.
\end{abstract}

\title{
Keywords:
}

Tax regulation; sustainability; microfinance; microfinance institutions

\section{Introduction}

After the introduction of the multicurrency system in 2009, Zimbabwe has experienced a rapid increase in the number of microfinance institutions (MFIs). These are mainly operating in urban centres with some opening branches at Growth Points to provide services to clients in the rural areas. Hardy, Holden and Prokopenko (2003:1) argue that MFIs serve a large number of clients, manage a significant loan portfolio and financial assets of the poor people. Hardy et al (2003:2) define a microfinance institution as "a financial institution that is characterised by its commitment to assisting typically poor households and small enterprises in gaining access to financial services." Such commitment can substitute or supplement shareholder value maximisation, direction of investment into priority sectors or mobilisation of savings to finance government operations (Hardy et al 2003:2). Main clients of MFIs consists of those who face severe barriers to access financial products from conventional financial institutions. Hardy et al further noted that the barriers of MFIs are mainly informed of high operational costs and risk factors caused by inconsistent income stream and lack of assets to provide for collateral security. The process of lending and taking deposits by MFIs enables households to smooth consumption and provide value in making and receiving payments and establishing a financial record. The above arguments raise the question that "How investors of MFIs, clients and microfinance businesses are taxable on their income, savings, and interest earned. Hardy et al contend that MFIs are well developed in countries like Bangladesh, Bolivia and Indonesia but have also been growing rapidly in developing countries in recent years. The authors note that MFIs take the form of credit unions/savings, co-operatives, private limited companies and other forms depending on the legal system of the country they operate.

In a study by Gallardo, Quattara, Randhawa and Steal in 2005, the supervision and regulation of MFIs should start when a MFI grow and start mobilising commercial resources beyond grants. They argued that in many developing countries, central banks lack clear understanding of microfinance methodologies and staff to supervise them. Gallardo et al (2005:7) were of the view that not all MFIs need to be regulated in an economy. This is because both regulated and unregulated MFIs would provide services on a sustainable basis under share performance standards and this encourages regulatory authorities to develop appropriate prudential regulations and staff capacity. Licencing of some MFIs in rural areas can facilitate the provision of services to specific markets.

Gallardo et al further contend that the regulation for microfinance activities take three forms: 1) simple registration of a legal entity; 2) non-prudential regulations that provide standards on business operations and oversight such as operating and financial reports to be submitted, to protect interests of clients and members; and 3) full prudential supervision. The authors defined prudential supervision as the verification by regulatory authorities of compliance by institutions with mandatory standards such as minimum capital requirements, liquidity management ratios and asset quality standards as a measure of financial soundness. Cull, Dermirgic and Morduch (2009:4) contend that prudential 
regulation is aimed specifically at protecting the financial system as a whole as well as protecting the safety of small deposits in individual institutions. Prudential regulation should generally be applied when a MFI accepts deposits from the general public. A MFI in form of co-operative groups or credit unions are beyond the reach and necessity of regulation but external supervision might be necessary at some stage of growth (Gallardo et al, 2005:8). Gallardo et al (2005:12) also claimed that most unregulated MFIs decentralise services by venturing into rural areas that banks and commercial MFIs find it too costly to reach.

Cull et al (2009:6) described non-prudential regulations as rules that govern a MFI's formation and operations, consumer protection, fraud prevention, establishing credit information services, interest rate limits, foreign ownership limitations, tax and accounting issues. Looking at Statements of Financial Position for MFIs, Hardy et al (2003:3) pointed out that many MFIs are usually small in financial terms with the total assets equivalent to only a few million dollars and capital rarely exceeds US\$1 million. The question that can arise is that: Is the MFI sophisticated enough to provide data on the total value of the assets it owns. This is important to the taxman since availability of such data can be used as a base for computing the tax liability of the respective MFI especially in the absence of income data. Addressing issues in the Income Statements of MFIs, Hardy et al (2003:4) suggested that costs incurred in microfinance business are normally high compared to the value of loans and deposits involved. These costs include administrative costs of making payments, keeping open offices, loan monitoring, and salaries. However, these costs are typically lower in commercial banks as the portfolio size increase.

Hardy et al further argued that high operational costs in MFIs force them to charge high interest rates on loans. Individuals and small businesses have no options but to borrow at higher interest rates from MFIs. However, for a self-sufficient MFI, with a large loan portfolio and number of borrowers, administrative costs are lower than the value of assets and deposits but their interest margin is higher because they attract lower-cost deposits (Hardy et al, 2003:4). Therefore, this calls for a sound system of recording transactions and reporting financial statements. Since MFIs are smaller in size compared to commercial or conventional banks, the question that emerge is does MFIs have the capacity to properly report their business transactions for tax purposes and does the tax liability affect their operational viability in addition to other administrative costs.

The regulation of MFIs should expand access to financial services by the poor as MFIs use microcredit as a tool for poverty alleviation and that financial sustainability exists and should continue to serve the poor without subsidy dependence (Gallardo, 2005:10). The regulation should promote fair and transparent business practices. Therefore, a tax regulation is effective when it is applied on reporting which is based on transparent business transactions. It is important to note that any regulation including licensing, supervision and taxation of MFIs should promote growth through enabling commercially-oriented MFIs to take deposits and attract investors in order to fund their growth (Gallardo, 2005:11). Gallardo further content that the costs of supervising MFIs are likely to be greater than those for commercial banks especially when MFIs outnumber the large banks. This in turn demands more personnel from the tax office to audit MFIs' activities. The fact that some MFIs are informal and do not keep proper books of accounts, and do not report their financial dealings, requires the tax office to understand the operations of MFIs and the information technology in use for reporting purposes if tax evasion is to be minimised.

Implementation of regulatory responsibilities fall into two areas: 1) regulatory policy should have a single locus; and 2) application of regulatory functions can be delegated to different regulatory units with specialised responsibilities (Gallardo, 2005:11). This means that as many registered MFIs are regulated by the central bank, tax collection and administration can be delegated to the tax authority.

As at 24 June 2016, 167 microfinance institutions were registered or licensed to operate in Zimbabwe (The Reserve Bank of Zimbabwe, 2016). Zimbabwe is one of the few countries in Southern Africa to pass a specialised law for microfinance businesses. The Microfinance Act, Chapter 24.29 was gazetted in 2013 to provide a holistic regulation and supervision of both credit-only and deposit taking MFIs (Deposit Protection Corporation, 2013). The Microfinance Act provides for the registration, supervision and regulation of persons conducting microfinance business in Zimbabwe. Makuyana 
(2016) argued that the distinction between credit-only and deposit taking microfinance institutions has not been that clear to the majority of potential microfinance clients. This has resulted in some rogue microfinance institutions in Zimbabwe taking deposits from the public even if they were registered as credit only MFIs. This resulted in the government losing revenue due to the emergence of some pyramid schemes. As a result the government lost a lot of tax revenue from such hidden transactions.

The Zimbabwe Revenue Authority (ZIMRA) is responsible for assessing, collecting and accounting for revenue on behalf of the State through the Ministry of Finance. ZIMRA collects revenue inform of custom duty, VAT, excise duty, income tax, Pay As You Earn, presumptive taxes, mining royalties, capital gains tax, and surtax. This raises the question as to how MFIs are managing to comply with the provisions of the tax regulation in addition to the Microfinance Act provisions. What is the effect of the of the tax system on MFI's profitability and provision of a variety of services to the poor individuals and small businesses?

\section{Literature review}

\subsection{Definitions}

Microfinance refers to methodologies used to make extremely small financial transactions at reasonable level of cost and affordability (Gallardo et al, 2005:13). The authors argued that the emergence of sustainable MFIs has enhanced the development of the financial sector in many countries that have undertaken macroeconomic and financial reforms by extending the reach of the financial system to new market niches and contributing to financial depending.

A financial sustainability MFI should not only provide credit but should take deposits, provide savings, insurance and other financial services to a large number of clients. Such MFIs should be able to borrow from the formal financial institutions, raise equity and accept deposits from the public (Gallardo et al, 2005:13). Cull et al argue that a financial self-sustainable MFI should find ways to absorb the costs of prudential regulation that leave their profits unchanged. In a different study by Gupta, Chaula and Harkawat (2012:3), a financial sustainability is the other indicator of performance of a MFI. The authors further argued that the term financial sustainability means having an operational sustainability level of 110 percentage or more. On the other hand operational sustainability is defined as total revenue divided by financial expense plus operating expenses. There are two kinds of sustainability used to assess MFI performance: 1) operational self-sustainability is when the operating income is sufficient enough to cover operational costs such as salaries, supplies, loan losses, and other administrative costs. Financial self-sustainability is when MFIs can also cover the costs of funds and other forms of subsidies received when they are valued at market prices (Gupta et al 2009:3). A sustainable microfinance acts as a financial intermediary that provides variety of financial services other than credit, reach households in different layers of poverty and clients have access to microfinance services that meet their requirements (Gallardo et al, 2001:6).

\subsection{Role of Microfinance Institutions}

MFIs are established to fill the gap left by large commercial financial institutions to provide financial services to poor households and small enterprises (Hardy et al, 2003:1). Most MFIs provide credit to disadvantaged sections of the society in small amounts which can be a difficult task to secure such loans from well-established commercial banks. Hardy et al argued that the main role of MFIs is to provide credit to poorer households and small businesses and may also take deposits. In addition to that MFIs can also offer other financial services such as insurance, advice and training to their clients, and education for example those in the fields of health awareness (Hardy et al, 2003:2). The above is supported by Gallardo (2005:7) who propounds that basic deposits, payments and credit services remained costly and beyond the reach of the poor because of complex collateral requirements of commercial banks. Therefore, the establishment of MFIs offer the potential to provide financial services to the poor and become commercially viable. 


\subsection{Designing of a regulatory framework}

A good legal and regulatory framework for microfinance involves adapting basic principles to conditions prevailing in a given country in terms of the range of institutions engaged in microfinance, the thresholds already established in the financial system and technical capacity of the regulatory authorities (Gallardo et al, 2005:9). Gallardo et al further argued that the development of a new tax regulatory framework for microfinance institution should be accompanied by complementary modifications of other business laws and regulations. This is because MFIs methodologies differ from the systems used in conventional commercial banks and other business organisations. The authors also mention that the creation of a microfinance tax regulation should be accompanied by substantial investment in raising awareness of policymakers consulting with stakeholders, improving systems and staff capabilities in MFIs to be regulated, and staffing up and training the supervisory authorities. The regulators should distinguish between deposit-taking MFIs, whose financial soundness would be verified through prudential supervision and those MFIs that may be subjected to non-prudential regulations but do not pose financial system risks for which the financial authorities bear responsibility (Gallardo et al 2005:12). Therefore, a tax regulation should be applied to both commercial MFIs and not-for-profit MFIs as some may hide by the name not-for-profit to evade tax.

According to the International Monetary Fund (2005) the key principles and standards for the design of a tax regulation for MFIs are different from those of large and conventional banks because the design must consider operational market and client characteristics of MFIs. The following principles should guide the design of a tax regulation for MFIs: 1) the tax regulation should provide a level playing field among participants in the provision of a range of financial services beyond credit and savings facilities; 2) to promote the institutional transformation of non-regulated MFIs into specialised, regulated or licensed rural finance and microfinance intermediaries; and 3) to promote and reward transparency in financial accounting and transaction reporting; and 4) to foster the exchange and sharing of credit histories of borrowing clients.

\subsection{Implementation of the regulation}

Gallardo et al (2005:9) contend that the law for microfinance should promote order in the sector. Nongovernmental organisations, donor projects and informal organisations should engage in microfinance if registered with the relevant authorities which is tasked to supervise the entire sector. Gallardo et al further argued that the regulatory requirements should facilitate the graduation of unregistered MFIs, into formal MFIs or regional or rural community banks. The setting up of a tax legislation should stimulate entry of new types of MFIs that help broaden and deepen access to financial services. This can be enhanced by provision of tax exemptions and tax incentives to MFIs. However, the tax authority should have the capacity to ensure that there is compliance by MFIs to the requirements of the applicable tax regulation.

Investors' return figures should incorporate the relevant tax rules including tax on interest for any kind of debt instrument, tax on capital gains for eventual sale, and withholding tax (Ledgerwood and White, 2006). Withholding tax is the tax the institution will need to withhold and remit to the relevant tax authority on any payment to an external party. The authors further argue that figures should be provided for both foreign and local investors because tax rates tend to differ between residents and non-residents in most countries. Countries may provide tax exemptions to MFIs. MFIs should consider the impact on profitability of losing the current tax exemptions. According to Ledgerwood and White (2006:202) a tax exemption mean that the MFI does not need to comply with tax reporting and filing requirements. However, MFIs may be required to meet tax reporting and filing requirements even if they owe no tax at all.

Ledgerwood and White (2006:205) posits that in some countries, taxes are charged on the net income or profits of the MFI irrespective of the designation of the MFI as a charitable organisation or the use to which such net income is put. In other countries a form over substance approach is taken by the tax authorities such that the legal form a MFI takes will determine its tax status. A MFI should determine the extent of the exemptions it qualifies from any tax type and the process by which to apply for it. A MFI needs to determine the type of expenses that can be deducted from income for purposes of 
calculating its net income (Ledgerwood and White, 2006:205). This in most cases depends on the sources of the income and may change with regulation. The general rule is to deduct all expenses incurred for the production of income when calculating net income for example interest payments made on microfinance loans. It is important for MFIs to engage tax advisors to assist on the extent of deductibility of expenses for a regulated MFI. This requires the keeping of appropriate records to support the requested deduction upon request by the tax authority (Ledgerwood and White, 2006:205). They also argued that in countries where the tax authority apply a different set of rules than those applied by bank regulators, a MFI may need to keep two sets of records regarding its loans one for bank regulatory purposes and one for tax regulatory purposes.

\subsection{Effectiveness of a tax regulation}

An effective tax rate is an average tax rate paid by the company on its earned income (Investopedia, 2014). An effective tax rate is calculated by dividing the income tax expenses by the income earned before taxes. This is supported by Schaffer and Turley, (2001) who suggested that the effectiveness of a tax system is measured by comparing statutory tax rates with effective yields. This involves the determination of the administrative capacity of a tax authority to enforce and collect tax from MFIs. According to Schaffer and Turley, this is determined by the ratio between statutory and effective tax rate denoted as follows:

Effective/statutory ratio $=\quad \mathrm{T}$

where $\mathrm{T}$ is the actual payments

$\mathrm{Y}$ is the gross tax base

$\mathrm{t}$ is the statutory tax rate applied to Gross Income

Schaffer and Turley (2001:4) said the above measures how close the effective tax rate is to the statutory tax rate. A ratio below 1 indicates that the effective tax yield is falling short of what application of the statutory tax rate would yield. A ratio close to 1 indicates that the effective tax rate is close to the statutory tax rate. An effective tax rate is one ratio investors use as a profitability indicator (Investopedia, 2014). In a study by Vitek and Pubal (2002), presented that tax effectiveness can mean the ability of the government to collect taxes with low costs. These costs include administrative cost of the tax system, which can be grouped as: 1) the sum of all administrative costs; 2) compliance costs; and 3) deadweight loss.

\subsection{Strategies for improving tax management systems by MFIs}

Ledgerwood and White (2006:202) noted that a MFI is expected to have a comprehensive tax management strategy which is split into:1) tax compliance and 2) tax planning. These require an initial understanding by a MFI of complex tax rules of filing and the payment obligations. On tax compliance the authors contend that a MFI can pay fines and penalties when it fails to meet the requirements of filing and remitting withheld amounts of tax to the tax authority. A MFI can engage tax advisors to assist itself in complying with its tax obligations (Ledgerwood and White, 2006:203). The services of the tax advisors would assist MFIs to be aware of: 1) the different tax forms that are required to be filed and the time the tax forms are due for submission; 2) the due dates for payment of tax liabilities; 3 ) the penalties charged for missing a filing or payment deadline; and 4) the types of recordkeeping required.

On the other hand, the authors noted that tax planning is appropriate when undertaken in a manner that does not compromise the MFI's tax compliance requirements. Tax planning should be commenced at earlier stages of business transformation as it aids better business transformation for better business decisions to be undertaken by MFIs. Ledgerwood and White also argued that decisions can be made on funding structure, regarding the difference in tax treatment of dividends and interest in determining whether to issue shares or debt to raise capital. The key to tax planning is a basic understanding of how taxable net income is calculated and if this will change the change of legal form 
or as a result of becoming regulated. This requires the understanding of what income is subject to tax, what type of expenses are deductible from gross revenue for the purpose of calculating net income and how long tax losses can be carried forward (Ledgerwood and White, 2006:204). They noted that the different types of taxes applied to MFIs are employer payroll tax, VAT, stamp duties and other national or local taxes.

\subsection{Overview of the Zimbabwean tax regulation}

Section 42 of the Microfinance Act stipulates the following: 1) each licenced MFI is required to keep proper accounts and other records related to its activities; 2) prepare financial statements at the end of each financial year reflecting the MFI's operations and financial condition; and 3) the accounts of a MFI should be audited by a person registered as a public auditor in terms of the Public Accountants and Auditors Act [Chapter 27:12].

Section 7 of the Income Tax Act [Chapter 23:06] stipulates that the income tax is computed on taxable income of an individual or organisation in the year of assessment using appropriate rates as fixed in the Finance Act from time to time. Section 15 of the Income Tax Act outlines that allowable deductions are deducted from income of a person or organisation so as to arrive at taxable income. Where a person earns income from trade, investment and income from employment amounts allowed to be deducted should only be claimed in respect of the production of income to which they relate.

Every person whose gross income does not consist solely of salary, wages or similar compensation for personal service should keep proper books and accounts of all his/her transactions and should retain for a period of six years form the last date of the last entry done in ledgers, cash books, journals, paid cheques, bank statements and deposit slips (Section 37B of the Income Tax Act). Any person who fails to keep proper records of transactions is liable to a fine equivalent of $10 \%$ of the person's taxable income or imprisonment for a period not exceeding three months. Records such as stock sheets, invoices, credit notes, debit notes, computer records should be open and made available for inspection by a ZIMRA official as may be required. A provision under section 41 stipulates that a return to investors in form of dividends or interest on deposits is subject to tax. However the Microfinance Act Chapter 24:29 prohibits the payment of dividends to investors of MFIs.

Section 14 of the Income Tax Act outline the following exemptions: any amount accruing by way of interest paid on any savings certificate; any deposit with a financial institution accruing to a taxpayer who is over the age of 55 years in respect of the first US\$3 000 in the year of assessment concerned; and value added tax. ZIMRA (2014) outlines that a registered or licensed organisation should pay provisional tax for each following year as follows: by $25^{\text {th }}$ of March $10 \% ; 25^{\text {th }}$ of June $25 \% ; 25^{\text {th }}$ of September $30 \%$ and $20^{\text {th }}$ of December $35 \%$ of the annual tax payable. For calculation of the provisional tax of each quarterly payment date, the organisation is required to estimate the annual tax due for the quarter. The annual estimated tax due should be revised to update the estimates every quarter. In Zimbabwe financial institutions are required to pay corporate tax, pay as you earn withholding tax and capital gains tax.

\section{Methodology}

This study follows the definition of MFIs by Hardy et al (2003) that include formal MFIs, informal MFIs, Credit Unions and Co-operatives. Following the same logic, data for this study was drawn from a survey which was administered to 8 managers and 24 loan officers from 16 MFIs, operating in Masvingo urban. A self-administered questionnaire was structured into two sections. The first section involved general questions about demographic information of participants. The second section addressed information relating to the tax regulation and sustainability of MFIs. The survey consisted of 24 statements. Using a five point Likert scale, participants were asked to place a tick in the space provided to indicate the extent of their agreement or disagreement with each statement. Prior to use, the questionnaire was pre-tested with two managers and two loan officers of MFIs. Questionnaires were coded with numeric values. The target population was made up of management and employees (loan officers) of MFIs. Responses were then recorded into a computer using a keyboard. SPSS was used to present and analyse the data. 


\section{Results}

In a sample of 32 participants, the majority of the employees are below 50 years of age with $88 \%$ whilst $12 \%$ are above 50 years. The majority of participants have formal education with $53 \%$ holding National Diplomas, followed by Higher National Diplomas with $28 \%$ and a significant $19 \%$ have a Bachelor's degree. This is not surprising as MFIs may find it expensive to pay highly qualified staff. We also found that the majority of the employees are recent graduates from Polytechnics with less than 10 years experiences. Other interesting results are that the majority of MFIs have less than six full-time employees which is represented by $81 \%$ whilst $19 \%$ have above six employees. On annual turnover, $25 \%$ of MFIs indicated that they earn up to US\$50 000, with 75\% claim that they earn between US\$50 000 and US\$1000 000. The majority earning above US\$50 000 are both deposit taking and offer credit to clients. The others which earn below $\$ 50000$ were mainly non-commercial MFIs (credit unions and co-operatives). Regarding the years in micro finance business $12.5 \%$ show that they are below five years of operation, $50 \%$ are between six to ten years, and $12.5 \%$ are above 10 years but less than 16 years while $25 \%$ are 16 years and above. This suggests that the majority of MFIs were formed recently.

A significant $42 \%$ indicated that the common taxes they pay are corporate tax and pay as you earn, Other taxes such as value added tax, withholding and presumptive tax are not common to MFIs. 58\% of MFIs showed that they are not aware of taxes that should be paid by MFIs. When asked to respond on whether MFIs are consulted in the designing of a tax regulation applicable to them, $80 \%$ revealed that they are not consulted whilst $20 \%$ were not sure. This means that the representation of MFIs at policy design level is very low.

$85 \%$ of the participants disagreed with the statement that the current tax regulation promotes growth and development of MFIs in Zimbabwe whilst $15 \%$ were of the opinion that it did promote growth and development of MFIs. This means that tax payments increase the burden of MFIs inform of compliance costs. $28 \%$ opined that they are aware of tax incentives available to MFIs, with $62 \%$ revealed that they are not aware and $10 \%$ were not sure. Other interesting results are that $68 \%$ showed that the profitability of a MFI increases when it transforms from being unregistered to a registered whilst $32 \%$ disagreed with the statement.

When responding to the awareness of tax exemptions available to MFIs, $68 \%$ of the participants revealed that they are not aware of tax exemptions offered to them by the government and 35\% showed that they are aware of the of the tax exemptions. It was also interesting to note that $55 \%$ of the participants viewed that payment of taxation by a MFI improves its financial performance and financial condition. However, $25 \%$ disagreed with the statement while $20 \%$ of the participants were not sure of the effect of paying tax. The main reason could be that a tax compliant MFI would not suffer from payment of penalties and fines and there are high chances of receiving government financial support in form of exemptions, grants, and tax exemptions.

A significant $60 \%$ of the participants opined that tax rates imposed to MFIs are too high, followed by $15 \%$ who feel that tax rates are fairly low, and lastly $35 \%$ were not sure of the level of the tax rates. On a different question, $10 \%$ of the participants agreed with the statement that unregistered MFIs pay tax while $90 \%$ of the participants disagreed with that. This means that a registered MFI has an extra burden of paying tax which is not suffered by a similar unregistered MFI. Such practice is against the principle of horizontal equity in a tax system. It was also noted that the majority of MFIs find it difficult to employ full-time Accounts professionals as represented by $80 \%$ of the participants while $20 \%$ showed that they have the capacity to employ and reward full-time Accounts professionals. On a related question, $35 \%$ of the participants revealed that MFIs normally consult tax advisors for assistance in tax planning and tax management issues while 35\% viewed that they manage their tax affairs on their own whilst $30 \%$ were not sure.

$20 \%$ of the participants noted that the payment of tax reduces the overall profit of a MFI, followed by $65 \%$ who felt that payment of tax insignificantly reduce the overall profit of a MFI, and $15 \%$ of the participants were not sure. The reason could be that the majority of MFIs are not paying corporate income tax. On another question $35 \%$ of the participants indicated that the tax rates chargeable to 
MFIs remain the same year after year, while 30\% revealed that the tax rates are regularly reviewed and $35 \%$ were not sure. This study also notes that employees and management of MFIs are not aware of tax forms required for filing by ZIMRA as represented by $62 \%$, a significant $25 \%$ indicated that they are aware of the tax forms to file, while $13 \%$ were not sure of the requirement. This necessitates the need to hire an accountant or to consult tax advisors for the assistance. However, it was interesting to note that the majority of MFIs are aware of the penalties and fines met when a MFI misses a tax filing requirement or tax payment deadline as indicated by $74 \%$ of the participants while $26 \%$ showed that they were not aware of that effect.

$15 \%$ of the participants showed that the current tax system provides incentives for registration and investment in microfinance business while $85 \%$ were not sure of the tax incentives on offer. In a different question, $56 \%$ of the participants disagreed with the statement that MFIs normally pay their taxes on or before the payment due date while $44 \%$ of the participants agreed with the statement. In another question, $63 \%$ of the participants recorded that MFIs mainly offer credit (loans) only to customers while $37 \%$ indicated that they take deposits as well as offering credit to customers. A significant $68 \%$ of the participants expressed that they do not rely on external financing to perform their functions whilst $22 \%$ argued that they got financial assistance from external sources. This suggests that the owners are the main source of capital for MFIs. 32\% of the participants revealed that their MFIs have branches both in town and at Growth points whilst 68\% suggested that they only operate in town.

Participants also indicated that the other factors that significantly influence the financial performance and growth of MFIs include: Microfinance regulation supervised by the Reserve Bank of Zimbabwe; inadequate capital; competition; registration procedures; minimum capital requirements; labour and rental costs; and non-performing loans.

\section{Discussion}

Formalising a MFI opens up more chances of securing the needed capital to fund operations and expand on MFI services. The findings suggest that a lack of significant educational campaigns by the government and lack of employees with tax knowledge complicates the interpretation and application of the tax legislation. The majority of the participants lacked the knowledge of tax exemptions made available to MFIs by the government. The general feeling was that tax rates were high and this negatively affects the fulfilment of tax obligations by MFIs. It has been observed that the hiring of qualified accountants and tax advisors is very expensive to MFIs due to high consultation fees. Tax incentives available to MFIs are not adequate enough to promote the investment in that sector. Services provided by MFIs to customers are mainly limited to deposit taking and provision of loans. This means that the majority of MFIs in Zimbabwe have not yet diversified their services as a way of upholding the livelihoods of the poor.

Table 1: Factors that influence the profitability and growth of MFIs

\section{Statistics}

\begin{tabular}{|c|c|c|c|c|c|c|c|}
\hline & & $\begin{array}{l}\text { Penalties } \\
\text { and fines }\end{array}$ & $\begin{array}{ll}\text { Low } & \text { tax } \\
\text { rates }\end{array}$ & $\begin{array}{l}\text { Registering } \\
\text { a MFI }\end{array}$ & $\begin{array}{l}\text { Tax } \\
\text { advisors } \\
\text { fees }\end{array}$ & $\begin{array}{l}\text { Record } \\
\text { keeping }\end{array}$ & $\begin{array}{l}\text { Tax } \\
\text { incentives }\end{array}$ \\
\hline $\mathrm{N}$ & Valid & 32 & 32 & 32 & 32 & 32 & 32 \\
\hline \multirow{2}{*}{\multicolumn{2}{|c|}{ Mean }} & 0 & 0 & 0 & 0 & & \\
\hline & & 4.0000 & 4.0938 & 2.9688 & 4.0313 & 4.0938 & 2.6563 \\
\hline \multicolumn{2}{|c|}{ Std. Deviation } & .91581 & .99545 & 1.37921 & .86077 & 1.05828 & 1.28539 \\
\hline \multicolumn{2}{|c|}{ Skewness } & -.806 & -1.453 & -.019 & -1.033 & -1.765 & .310 \\
\hline \multicolumn{2}{|c|}{ Std. Error of Skewness } & .414 & .414 & .414 & .414 & .414 & .414 \\
\hline \multicolumn{2}{|c|}{ Minimum } & 2.00 & 1.00 & 1.00 & 2.00 & 1.00 & 1.00 \\
\hline \multicolumn{2}{|c|}{ Maximum } & 5.00 & 5.00 & 5.00 & 5.00 & 5.00 & 5.00 \\
\hline
\end{tabular}


Table 1 shows that when a MFI do not pay penalties and fines, a particular MFI tends to record higher net profit as indicated by the mean of 4 which was represented by agree on the statement. Low tax rates for any type of tax would leave a MFI with enough profits to expand on its services to the poor without looking for external assistance thus being financially independent. Registering a MFI do not affect much the profitability and growth potential of a MFI as indicated by a mean of 2.9 meaning that the majority of the participants were recorded between disagree and not sure with the statement. The general opinion from the participants suggest that tax advisors fees affected much the net profit of a MFI as indicated by the mean case of 4 for agreeing with the statement. Record keeping requirements affect the profitability and growth of a MFI. This is because labour costs are going to increase by hiring qualified accountants to assist in the process. Tax incentives do not affect much the profitability and growth of a MFI as the majority of participants are not aware and are not utilising the available tax incentives for the benefit of their businesses.

\section{Conclusion and recommendations}

Generally MFIs are not aware of tax provisions that outline tax exemptions and tax incentives available to MFIs. MFIs proved that they are not obtaining much financial assistance from external sources such as the government, banks or Non-Governmental organisations. It can be concluded that currently they are too many types of taxes that should be paid by MFIs and the majority of MFIs are only paying Pay As You Earn (PAYE) and as a result they suffer much penalties and fines. Generally it can be concluded that a tax regulation can enhance the sustainability of MFIs if properly simplified to promote investment in microfinance business through provision of exemptions, tax incentives, free registration, simplified record keeping procedures, and reduced tax rates. This calls for robust educational workshops and seminars across the country so that MFIs can reduce costs of hiring parttime tax professionals. There is need to have a specific tax system to MFIs that separate them from the tax regulation applicable to large financial institutions. MFIs should be given a less tax burden by the government because it is the poor who are being taxed in the sense that MFIs provide loans to the poor which they otherwise would not get from classical banks. Loans from MFIs are more expensive because the tax is incorporated in the cost of a loan. Therefore, MFIs should not be heavily taxed if they are to meet a major objective of poverty alleviation. The tax regulation should allow MFIs to pay their taxes only once per year after the end of the trading financial year rather than the current requirement of remitting corporate tax on a quarterly basis to serve labour costs and compliant costs.

\section{References}

Cull, R., Demirguc, A. \& Morduch, J., 2009. Does regulatory supervision curtail Microfinance profitability and outreach.

[Online]

Available at: www.worldbank.org

Deposit Protection Corporation Zimbabwe, 2013. Microfinance Act Chapter 24:29. [Online] Available at: www.dpcorp.co.zw

Engelshalk, M., 2007. Designing a tax system for micro and small business: guide for practitioners, Washington DC: World Bank .

Gallardo, J., 2001. A framework for regulating Microfinance Institutions: The experiences in Ghana and the Phillipines, s.l.: The World Bank.

Gallardo, J., Quattara, K., Randhawa, B. \& Steel, W. F., 2005. Comparative review of Microfinance regulatory framework issues in Benin, Ghana and Tanzania. [Online] Available at: www.worldbank.org

Gupta, S. V., Chaula, P. M. \& Harkawat, S., 2012. Measuring performance of microfinace institutions in india. Annamalai International Journal of Business Studies and Research, pp. 14-23.

Hardy, D. C., Holden, P. \& Prokopenko, V., 2003. Microfinance Institutions and Public Policy. Policy Reform, pp. 147-158. 
International Monetary Fund, 2005. Financial Sector Assessment: Rural and Microfinace InstitutionsRegulatory and Supervisory Issues. s.l.:IMF.

Investopedia, 2014. How are effective tax rates calculated from income statements. [Online] Available at: www.investopedia.com

Ledgerwood, J. \& White, V., 2006. Transforming Microfinance Institutions: Providing full financial services to the poor. [Online] Available at: www.worldbank.org

Makuyana, T., 2016. Microfinace regulation and supervision in Zimbabwe: A critical overview. Mediterranean Journal of Social Sciences.

Schaffer, G. \& Turley, G., 2001. Effective versus stautory taxation: measuring effective tax administration in transition economies, s.1.: European Bank.

The Reserve Bank of Zimbabwe, 2016. List and details of registered MFIs. [Online] Available at: www.rbz.co.zw

The Reserve Bank of Zimbabwe, 2016. Microfinance Institutions. [Online] Available at: www.rbz.co.zw

Vitek, L. \& Pubal, K., 2002. Evaluation of the effectiveness of the tax collectioon. The case of the Czech central and Local Governments, Prague: United Nations Public Administration Network.

Vitek, L. \& Pubal, K., 2002. Evaluation of the effectiveness of the tax collection. The case of the Czech Central and Local Government. , Prague: United Nations Public Adminstration Network.

ZIMRA, 2014. Income Tax Act Chapter 23:06. [Online] Available at: www.zimra.co.zw

$\begin{array}{lllll}\text { ZIMRA, } 2014 . & \text { What } & \text { does. }\end{array}$

Available at: www.zimra.co.zw 